\title{
Regional Research in the History of Education - Methodological Problems
}

\begin{abstract}
The article demonstrates in what way the popularity of the problems of regional studies influences the development of learning (including the history of education), local societies and, paradoxically, the evolution of global history. Additionally, the author of the article gives reasons, apart from globalization phenomena and the uniting of Europe, is the methodological "revolution" in the field of social sciences, which has significantly altrered the resarch perspective of historians.
\end{abstract}

Keywords: regional research, history of education in Poland

Simone Weil wrote that "putting down roots is perhaps the most important and most familiar need of the human soul. At the same time, it is a need that is difficult to determine. A human being has roots if he/she actively and naturally participates in the existence of a community, which stores certain treasures from the past and has a sense of tomorrow ${ }^{1}$." The historian's need is, on the other hand, to study the phenomenon of putting down roots, to try to define and explain it, as "it is from history that regionalists derive the desire to preserve identity, protect regional values and care for their heritage, making it the foundation of education and the reason of school pride ${ }^{2}$.

The key term in this work is the concept of "regionalism". It can be explained in three ways: as a socio-cultural movement, striving to preserve the specific features of the culture of a given area, to deepen knowledge about a particular culture, its development and renewal; as the culture of a given region, as a set of characteristics of a given region; as

1 WEIL, S., Myśli, Warsaw 1985, p. 144.

2 OMELANIUK, A.J., Do uczestników XVI Powszechnego Zjazdu Historyków Polskich, [in:] Region i ludzie a historiografia i tożsamość. Materiały z II Zjazdu Historyków Regionalistów w Gdańsku - Starbieninie 22-24 XI 1996, introduction by J. BORZYSZKOWSKI, Gdańsk-Ciechanów 1999, p. 5. 
a pronunciation feature, a grammatical form, an expression or a syntactic construct characteristic for the speech of a certain region of the country ${ }^{3}$.

Another understanding of this term is the concept of regionalism as a socio-cultural current striving to preserve the unique cultural characteristics of the area, its renewal and promotion, a current that has played an important role in the formation of nationalist movements. In addition, regionalism may be understood as a socio-cultural movement based on the interest in the cultural distinctiveness of the country's individual regions, striving to deepen and present knowledge about this culture (e.g. through the activities of regional associations) ${ }^{4}$.

The term regionalism is also a historical category. And in this sense it has undergone numerous changes over the course of history, in analogy to the transformation of social regional consciousness. In Poland, the traditions of regionalism are extremely vivid, caused by the turmoil of Polish history (the partitions). Firstly, regional themes appeared in literature (S. Witkiewicz, F. Ceynowa, T. Przerwa-Tetmajer, W. Orkan, E. Zegadłowicz), and then, also in science. In the interwar period, the movement for the dissemination of knowledge and regional values gained momentum. In 1926, the official "Program of Polish Regionalism" was announced (initiated in the Section of Regional General Universities, functioning at the Union of Polish Teachers of Common Schools). According to T. Aleksander, it [this movement - E.G.S] "was carried out [...] through school teaching, after-school activities, tourism and sightseeing. Teachers, creators of various educational institutions, who reached out to the region's values, initiators of the youth tourism movement - authors of guidebooks and sightseeing books, played an important role in this movement ${ }^{5}$." A special figure is Aleksander Patkowski, a teacher, and also a great fan of Sandomierz Land, a devotee and promoter of sightseeing tours, initiator and organizer of the First National Sightseeing Congress held in Poznań in 19296. Kazimierz Sosnowski played a similar role for the Małopolska region?

Another term that requires clarification is the concept of "regional research". According to J. Topolski, this term includes "the attempts made by numerous 'devotees' of history to show local 'antiquity', i.e. remarkable facts, people or places, derived from the nineteenth-century awakening of historical consciousness ${ }^{8} . "$ The immediate manifestation of this awakening was the emergence of not only numerous social associations, but above all,

3 PETRYKOWSKI,P., Regionalizm, [in:] Encyklopedia pedagogiczna XXI wieku, ed. T. PILCH, vol. 5, Warsaw 2006, p. 130.

${ }^{4}$ Ibidem.

5 ALEKSANDER, T., Regionalizm a wychowanie, [in:] Encyklopedia pedagogiczna XXI wieku, ed. T. PILCH, vol. 5, Warsaw 2006, p. 138.

${ }^{6}$ More information on Aleksander Kazimierz Patkowski in, inter alia: KOŹMIAN, D., Poglady społeczno-pedagogiczne Aleksandra Kazimierza Patkowskiego (1890-1942), Szczecin 1994; ŻOŁĄDŹ-STRZELCZYK, D., JAMROŻEK, W., Edukacja regionalna w ujęciu Aleksandra Kazimierza Patkowskiego, [in:] Edukacja regionalna, ed. A.W. BRZEZIŃSKA at all, Warsaw 2006.

${ }^{7}$ ALEKSANDER, T., op. cit., p. 139.

${ }^{8}$ TOPOLSKI, J., Marksizm i historia, Warsaw 1977, p. 423. 
the publication of various historical publications, mainly the so-called local monographs ${ }^{9}$. For Topolski, this type of study is nothing new. This particular historian reminds us that similar works had already been created in antiquity. Were the Greek chronicles not a sign of interest in regional research ${ }^{10}$ ?

This researcher also explains the concept of "historical region" for the needs of the reconstruction of regional research. Thus, according to Topolski, this is "a specific territory, inhabited by people connected by common, longer or shorter, history - different $[\ldots]$ from the history of other territorial and population units. The historical region, therefore, is a certain [...] structural system, characterized by its own historical distinctiveness, sometimes separate administrative boundaries, i.e. one that may be the subject of synthetic research, namely, referring to the whole being the region of scientific research. In other words, it is a social-economic, political and administrative, cultural and psychological system, with considerable weight of individual elements in different historical periods that can be distinguished from a wider historical fabric. The historical region is primarily associated with the problems of people, and not geographical issues ${ }^{11}$."

Researchers, especially those in the field of social sciences, explain the growing interest in regional issues as a response to metanarratives (Z. Melosik, K. Kossak-Główczewski) or as a form of rebellion against globalization and a vision of the world depicted as a global village (J. Borzyszkowski, J. Damrosz, H. Skorowski). Z. Bauman writes that "we are 'globalized' and being 'globalized' means almost the same for everyone who is affected by this process ${ }^{12}$." There are also theories that the return to regional research and regional problems is the result of the release of social energy during political transformation (M. Ciechocińska, S. Gawlik), and finally there are theories that portray regionalism as a natural process of differentiation in the conditions of a uniting Europe (S. Dąbrowski, K. Kwaśniewski, W. Świątkiewicz) ${ }^{13}$.

In the context of reflections on regional issues, historical studies, and in particular educational history, occupy a significant and special place. Not only because of the significant number of teachers, schools or youth organizations promoting regionalism, or the above-mentioned problems with understanding and translating the concept, but also due to the dozens of years of methodological revolution in social sciences ${ }^{14}$. This revolution, often referred to as an anti-positivist breakthrough, meant an opposition to the traditional model of positivist science, which marked a rebellion against the "reigning" factograph-

\footnotetext{
9 Ibidem.
}

10 Ibidem, p. 424.

11 Ibidem, p. 430.

12 BAUMAN, Z., Globalizacja. I co z tego dla ludzi wynika, Warsaw 2000, p. 5. See: SARNAT, A., Odrębność narodowa i regionalna na tle procesów globalizacji, [in:] Między tradycja a nowoczesnościa, ed. K. RĘDZIŃSKI, Częstochowa 2007, p. 67-82.

${ }^{13}$ Re: ALEKSANDER, T., op. cit. See: MAKOWSKI, K. A., Wstęp, [in:] O nowy model historycznych badań regionalnych, ed. K. A. MAKOWSKI, Poznań 2007, p. 7-8.

14 TOPOLSKI, J., “O przedmiocie i metodologii badań regionalnych w zakresie historii oświaty”, Przegląd Historyczno-Oświatowy, 1981, no. 2, p. 171. 
ic, descriptive, and "event-related" (evenementielle) historiography ${ }^{15}$. The methodological revolution was to change the research perspective of the historians from factual to theoretical-explanatory, instead of "what happened", the idea of "why it happened" became more appealing. On the other hand, such a view on science "forced" researchers to conduct interdisciplinary studies, or in other words, as proposed by scholars from the "Annales" school, create a "common market for human sciences ${ }^{16}$."

As J. Topolski observed, such a radical change in the research on the past was not intended to diminish the current achievements (including also in the field of regional research), but to give it a different - more important and more relevant rank ${ }^{17}$. The promoters of the "new" trend wanted not only to avoid learning just for learning's sake, but also to avoid amateurism, which according to many researchers was quite universal ${ }^{18}$. W. Molik even claimed that "historians themselves contribute greatly to the degradation of their profession. Not only do they allow persons without proper professional preparation to enter the profession, but they also support and promote them by writing laudations and prefaces to their superficial books which contain serious substantive errors. [...] The de-professionalization of the Polish historiographer is a disturbing fact to some historians, but the attempts to oppose this unfavorable phenomenon are rare. The tendency to sanction it is more visible 19 ." As this type of phenomena is universal, it is difficult to clarify the "general needs", that is: the need for explanation ("facts must be collected" because they are necessary for clarification) and the need for synthesis ("facts must be collected" as they are necessary for general and synthetic approaches) ${ }^{20}$.

In view of the above, all kinds of "partial research", which include regional research, play a very important role. Researchers - historians of education who carry out such research should be aware of the new methodological attitude and the problems that should be the source of their reflection:

1) the general assumptions of modern historical research (inter alia: the postulated interdisciplinarity);

2) the place of the widely understood education in the historical process;

${ }^{15}$ Re. e.g.: GŁOWACKA SOBIECH, E., "Dzieje oświaty i myśli edukacyjnej w systemie nauk historycznych (wstęp do dyskusji)", Eużyckie Zeszyty Naukowe, 2005, no. 1, p. 22-26.

16 SZACKI, J., Historia myśli socjologicznej, Warsaw 2002, p. 733. Re: DĘBICKI, J., HARC, L., Interdyscyplinarność albo zintegrowanie dyscyplin a historyczne badania regionalne (na przykładzie Ślaska), [in:] Mundus hominis - cywilizacja, kultura, nauka. Wokót interdyscyplinarności badań historycznych, ed. S. ROSIK and P. WISZEWSKI, Wrocław 2006, p. 438.

17 TOPOLSKI, J., O przedmiocie i metodologii badań regionalnych, p. 173.

${ }_{18}$ MOLIK, W., O nowy model syntezy dziejów regionu na przykładzie Wielkopolski, [in:] O nowy model historycznych badań regionalnych, p. 16.

${ }^{19}$ Ibidem. Also see: HELLWIG, J., O naukowy charakter opracowań regionalnych z zakresu historii wychowania, [in:] Idem, Prolegomena do historii wychowania, Poznań 1995, p. 79.

${ }^{20}$ TOPOLSKI, J., O przedmiocie i metodologii, p. 173. 
3) the place and role of the region included in the research in the nation's overall history $^{21}$.

On the other hand, J. Topolski notes that two types of practicing regional history (university history and local history - cultivated outside of scientific centres) were distinguished in the nineteenth century, when history became a university discipline and the previously mentioned awakening of historical consciousness took place. In the area of research, this resulted in a "division of labour", primarily in the territorial sense: problems concerning the entire nation, the state, and common history became the domain of university historiography, while local problems - "were the domain of people working in the historical field in a given area ${ }^{22}$." From the methodological point of view, there were no major discrepancies between the two currents of history in the nineteenth century, because "in general there was the same misunderstanding of theory, which resulted in following the same philosophical assumptions. This was a popular, common-sense assumption, more or less disturbed by various kinds of national myths, often by clericalism, similar political views ${ }^{23}$." J. Topolski also points out that "the love for historical research" by "the little ones" was also an effect of the state of knowledge of the contemporary society, as "lower-secondary schools at that time passed on more knowledge in the subject than today's schools. Therefore, they prepared larger groups of intelligentsia for carrying out regional research, often on an amateur level - by providing wide philological and humanistic foundations to all students, and as a consequence to representatives of various professions ${ }^{24}$." A breakthrough in historical science at the turn of the 19th and 20th centuries left amateur regional research far behind.

The history of education, the history of teaching is a sub-discipline of pedagogy, being a science about education and an important part of cultural history ${ }^{25}$. B. Suchodolski admitted that "this science covers both the history of pedagogical thought and pedagogical practice, that is, educational institutions in the context of cultural history ${ }^{26}$." A similar view was presented by an outstanding historian of education $\mathrm{S}$. $\operatorname{Kot}^{27}$. The understanding of culture not only as a process, but also as a state, influenced the perception of education and created a stronger "link" with regional issues. After all, the formation of regional territories is not a closed process, their borders have been and are changing ${ }^{28}$. This is especially evident in the study of lands whose history was full of turmoil and whose nationality has

${ }^{21}$ Ibidem, p. 175.

22 TOPOLSKI, J., Marksizm i historia, p. 424.

23 Ibidem, p. 425.

${ }^{24}$ Ibidem.

${ }_{25}$ MAJEWSKI, S., Historia wychowania, [in:] Encyklopedia Pedagogiczna XXI wieku, ed. T. PILCH, vol. 2, Warsaw 2003, p. 223. See: TOPOLSKI, J., O przedmiocie i metodologii, p. 177.

${ }^{26}$ Re: MAJEWSKI, S., op.cit., p. 223.

${ }^{27}$ Re: Ibidem.

28 SZCZECHURA, T., "Głos w dyskusji nad rolą badań regionalnych”, Przegląd Historyczno-Oświatowy, 1981, no. 2, p. 184. 
changed many times (this applies, for example, to the so-called Regained Territories) ${ }^{29}$. J. Topolski sums it up when he writes that "human history is a constant, dynamic process of creating, disappearing and transforming regions ${ }^{30}$."

"The practice" of regional history, in particular concerning the issue of upbringing and education, is highly desirable. First of all, it constitutes the above-mentioned "partial research", which is important for building syntheses and writing general works, and secondly, it is "a lever of intellectual and cultural life in an area devoid of centres of scientific life ${ }^{31}$." It is also in line with the latest "trends" in historiography, in which issues such as sewerage, language, road development, and other "minor" issues remain as important as matters related to dynasties, pacts and wars $^{32}$. In foreign publications, this trend has been discovered a long time ago (e.g.: in the already mentioned movement - the Annales school),whereas in Poland it still has numerous opponents. In addition, there is no methodological specificity of regional research. The same assumptions and methodological directives apply to all historical research ${ }^{33}$. The most typical types of historical regional research are: urban monographs, monographs of certain territories and various types of detailed research ${ }^{34}$.

This penetration of contemporary trends in historiography with regional history was aptly assessed by J. Borzyszkowski when he wrote that it corresponds to "a return to the roots, to the role of man as an individual, co-creation of history and its responsibility for today and tomorrow, or only the local homeland. Sometimes this local [...] is both small and big. We often recall - not just us, historians - regionalists - the Latin maxim "History is the teacher of life". It makes sense as long as we really try to recognize and learn history. History is not a teacher in itself, because at the same time there are too many phenomena, facts confirming the idealization of the past, manifestations of the desire to return to the past, and failing to learn from history ${ }^{35}$."

\section{Bibliography}

ALEKSANDER, P., Regionalizm, [in:] Encyklopedia Pedagogiczna XXI wieku, ed. T. Pilch, vol.5, Warsaw 2006.

BAUMAN, Z., Globalizacja. I co z tego dla ludzi wynika, Warsaw 2000.

${ }^{29}$ DĘBICKI, J., HARC, L., op.cit., p. 446.

30 TOPOLSKI, J., Marksizm i historia, p. 431.

31 SZCZECHURA, T., op. cit.

32 DOMAŃSKA, E. writes about these micro-histories in her book: Mikrohistorie. Spotkania w międzyświatach, Poznań 2005.

33 TOPOLSKI, J., Marksizm i historia, p. 433.

34 Ibidem, p. 434.

${ }^{35}$ BORZYSZKOWSKI, J., Wstęp, [in:] Region i ludzie, p. 8-9. See: HELLWIG, J., "O potrzebie badań metodologicznych w historii wychowania”, Przegląd Historyczno-Oświatowy, 1999, no. 3-4, p. 171. 
BORZYSZKOWSKI, J., Wstęp, [in:] Region i ludzie a historiografia i tożsamość. Materiaty z II Zjazdu Historyków Regionalistów w Gdańsku - Starbieninie 22-24 XI 1996, introduction by J. BORZYSZKOWSKI, Gdańsk - Ciechanów 1999.

DĘBICKI, J., HARC, L., Interdyscyplinarność albo zintegrowanie dyscyplin a historyczne badania regionalne (na przyktadzie Śląska, [in:] Mondus hominis - cywilizacja, kultura, nauka. Wokót interdyscyplinarności, ed. S.ROSIK and P. WISZEWSKI, Wrocław 2006.

DOMAŃSKA, E. Mikrohistorie. Spotkania w międzyświatach, Poznań 2005.

GŁOWACKA - SOBIECH, E., „Dzieje oświaty i myśli edukacyjnej w systemie nauk historycznych (wstęp do dyskusji)", Łużyckie Zeszyty Naukowe, 2005, no.2, p. 22-26.

HELLWIG, J., „O potrzebie badań metodologicznych w historii wychowania”, Przeglad Historyczno -Oświatowy, 1999, no. 3-4.

HELLWIG, J., Prolegomena do historii wychowania, Poznań 1995.

KOŹMIAN, D., Poglady społeczno - pedagogiczne Aleksandra Kazimierza Patkowskiego (1890 1942), Szczecin 1994.

MAJEWSKI, S., Historia wychowania, [in:] Encyklopedia Pedagogiczna XXI wieku, ed. T. Pilch, vol.2, Warsaw 2003.

MAKOWSKI, K.A., Wstęp, [in:] O nowy model historycznych badań regionalnych, ed. K.A. MAKOWSKI, Poznań 2007.

MOLIK, W., O nowy model syntezy dziejów regionu na przykładzie Wielkopolski, [in:] O nowy model historycznych badań regionalnych, ed. K.A. MAKOWSKI, Poznań 2007.

OMELIANIUK, A.J., Do uczestników XVI Powszechnego Zjazdu Historyków Polskich, [in:] Region i ludzie a historiografia i tożsamość. Materiaty z II Zjazdu Historyków Regionalistów w Gdańsku - Starbieninie 22-24 XI 1996, introduction by J. BORZYSZKOWSKI, Gdańsk Ciechanów 1999.

PETRYKOWSKI, P., Regionalizm, [in:] Encyklopedia Pedagogiczna XXI wieku, ed. T. Pilch, vol. 5, Warsaw 2006.

SARNAT, A., Odrębność narodowa i regionalna ba tle procesów globalizacji, [in:] Między tradycja a nowoczesnością, ed. K. RĘDZIŃSKI, Częstochowa 2007.

SZACKI, J. Historia myśli socjologicznej, Warsaw 2002.

SZCZECHURA, T., „Głos w dyskusji nad rola badań regionalnych”, Przegląd Historyczno-Oświatowy, 1981, no.2.

TOPOLSKI, J., Marksizm i historia, Warsaw 1977.

TOPOLSKI, J., „O przedmiocie i metodologii badań regionalnych w zakresie historii oświaty”, Przeglad Historyczno-Oświatowy, 1981, no.2.

WEIL, S., Myśli, Warsaw 1985.

ŻOŁĄDŹ-STRZELCZYK, D., JAMROŻEK, W., Edukacja regionalna w ujęciu Aleksandra Kazimierza Patkowskiego, [in:] Edukacja regionalna, ed. A. W. BRZEZIŃSKA at all, Warsaw 2006. 
